May 2002 • NREL/CP-520-31442

\title{
Float-Zone and Czochralski Crystal Growth and Diagnostic Solar Cell Evaluation of a New Solar-Grade Feedstock Source
}

\author{
Preprint
}

T.F. Ciszek, M.R. Page, T.H. Wang, and J.A. Casey

To be presented at the $29^{\text {th }}$ IEEE PV Specialists Conference New Orleans, Louisiana May 20-24, 2002
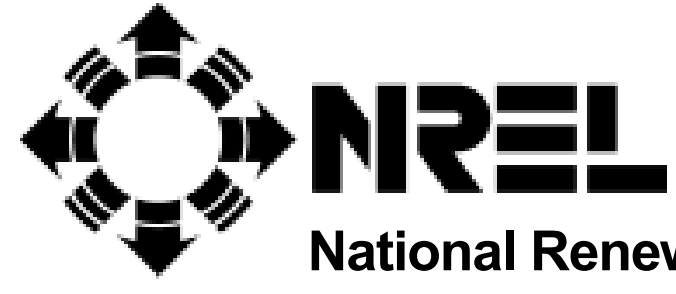

National Renewable Energy Laboratory

1617 Cole Boulevard

Golden, Colorado 80401-3393

NREL is a U.S. Department of Energy Laboratory

Operated by Midwest Research Institute $\bullet$ Battelle $\bullet$ Bechtel

Contract No. DE-AC36-99-G010337 


\section{NOTICE}

The submitted manuscript has been offered by an employee of the Midwest Research Institute (MRI), a contractor of the US Government under Contract No. DE-AC36-99G010337. Accordingly, the US Government and MRI retain a nonexclusive royalty-free license to publish or reproduce the published form of this contribution, or allow others to do so, for US Government purposes.

This report was prepared as an account of work sponsored by an agency of the United States government. Neither the United States government nor any agency thereof, nor any of their employees, makes any warranty, express or implied, or assumes any legal liability or responsibility for the accuracy, completeness, or usefulness of any information, apparatus, product, or process disclosed, or represents that its use would not infringe privately owned rights. Reference herein to any specific commercial product, process, or service by trade name, trademark, manufacturer, or otherwise does not necessarily constitute or imply its endorsement, recommendation, or favoring by the United States government or any agency thereof. The views and opinions of authors expressed herein do not necessarily state or reflect those of the United States government or any agency thereof.

Available electronically at http://www.osti.gov/bridge

Available for a processing fee to U.S. Department of Energy and its contractors, in paper, from:

U.S. Department of Energy

Office of Scientific and Technical Information

P.O. Box 62

Oak Ridge, TN 37831-0062

phone: 865.576 .8401

fax: 865.576.5728

email: reports@adonis.osti.gov

Available for sale to the public, in paper, from:

U.S. Department of Commerce

National Technical Information Service

5285 Port Royal Road

Springfield, VA 22161

phone: 800.553 .6847

fax: 703.605.6900

email: orders@ntis.fedworld.gov

online ordering: http://www.ntis.gov/ordering.htm

Printed on paper containing at least $50 \%$ wastepaper, including $20 \%$ postconsumer waste 


\title{
FLOAT-ZONE AND CZOCHRALSKI CRYSTAL GROWTH AND DIAGNOSTIC SOLAR CELL EVALUATION OF A NEW SOLAR-GRADE FEEDSTOCK SOURCE
}

\author{
T.F. Ciszek*, M.R. Page, T.H. Wang, and J.A. Casey \\ National Renewable Energy Laboratory, Golden, CO 80401 USA
}

\begin{abstract}
Czochralski (CZ) and float-zone (FZ) crystals were grown from experimental solar-grade silicon (SOG-Si) feedstock materials developed by Crystal Systems. The materials were metallurgical-grade $\mathrm{Si}$ and highly borondoped p-type electronic-grade Si (EG-Si) reject material, both of which were gaseous melt-treated to remove boron. Crystal growth observations, lifetime and impurity characterization of the grown crystals, and device performance of wafers from them are presented. Devices made directly on treated high-B EG-Si feedstock have a little over half the efficiency of devices made from control CZ samples. However, devices on CZ and FZ crystals grown from the treated high-B EG-Si feedstock have comparable PV performance $(14.0 \%$ and $13.8 \%$ efficiency, respectively) to that of $\mathrm{CZ}$ control samples (14.1\%).
\end{abstract}

\section{INTRODUCTION}

A solar-grade silicon (SoG-Si) feedstock formation method under investigation by Crystal Systems (Salem, MA) treats molten metallurgical-grade silicon (MG-Si) with a sequence of gaseous and slagging processes to reduce impurities. The method has been particularly successful with boron impurity removal [1], although residual levels of phosphorous are higher than desired so far. The success with boron removal, historically considered to be one of the most difficult impurities to remove from silicon because of its low volatility and low segregation coefficient, could open the way to interim utilization of a heretofore unusable segment of the scrap electronic-grade silicon (EG-Si) supply. This is heavily boron-doped singlecrystal, wafer, and epitaxial-wafer reject material. We grew Czochralski (CZ) and float-zone (FZ) crystals using Crystal Systems-treated MG-Si and particularly their treated highly boron-doped p-type EG-Si reject material as the feedstock. Observations on crystal growth, characterization of the grown crystals, and device performance of wafers from them are presented.

\section{FEEDSTOCK MATERIAL}

Working under a DOE-NREL PVMaT subcontract, Crystal Systems developed gaseous and slagging melt treatments focused toward an eventual cost-effective pro- cess for making SoG-Si feedstock from MG-Si. In using these treatment sequences on MG-Si, boron levels could be reduced from $20-60$ ppma to $\sim 0.3$ ppma $(1 \Omega-\mathrm{cm})$, but phosphorous and carbon removal remain a problem. The treatment process was recently applied to highly borondoped EG-Si scrap (boron content of 50-400 ppma). The available amount of this material is estimated to be equivalent to 100-200 MW/year. The Crystal Systems process reduces its boron content by several orders of magnitude, to approximately 1 ppma $(0.4 \Omega-\mathrm{cm}$, or $5 \mathrm{x}$ $10^{16} \mathrm{~cm}^{-3}$ ). Batch sizes of 60 to $140 \mathrm{~kg}$ have been treated. Although an integrated treatment procedure might process liquid silicon directly as it is tapped from the arc furnace in a MG-Si plant, followed by in situ slow directional solidification of a multicrystalline ingot for wafering into cell blanks, the smaller-scale initial experiments considered only the melt treatment step. Solid MG-Si or boron- doped reject EG-Si was loaded into a crucible and melted, treated, and solidified, but the directional solidification was sub optimal for direct ingot use because a dual-use furnace with proper features for both treatment and directional solidification has not yet been implemented. The solidified, treated silicon was core drilled to form feed rods for FZ growth and crucible charges for $\mathrm{CZ}$ growth. The shaped pieces were degreased and etched in 3:1:2 mixed acid prior to crystal growth. The treated high-B EG-Si and MG-Si feedstock are both dense and remain intact through shaping, cleaning, and etching steps. They are also suitable as substrates for epitaxial growth.

\section{FLOAT-ZONE AND CZOCHRALSKI CRYSTAL GROWTH}

\section{Float-zone growth}

FZ growth was carried out on treated high-boron content scrap EG-Si using RF heating with a stationary one-turn coil operating at $2 \mathrm{MHz}$ in an argon ambient at 0.3 bar above atmospheric pressure, to minimize heater or crucible sources of $\mathrm{O}, \mathrm{C}$, and other impurities. The feedstock diameter was about $27 \mathrm{~mm}$, and crystals of this diameter or somewhat larger were grown. The typical growth rate was $3 \mathrm{~mm} / \mathrm{min}$ with a 13-16 rpm crystal rotation rate and a 2-3 rpm feed rod rotation rate (crystal on the bottom, moving downward). A clean initial melt allowed good seed contact and initiation of dislocation-free (DF) growth. No gas evolution or cracking of the feed- 


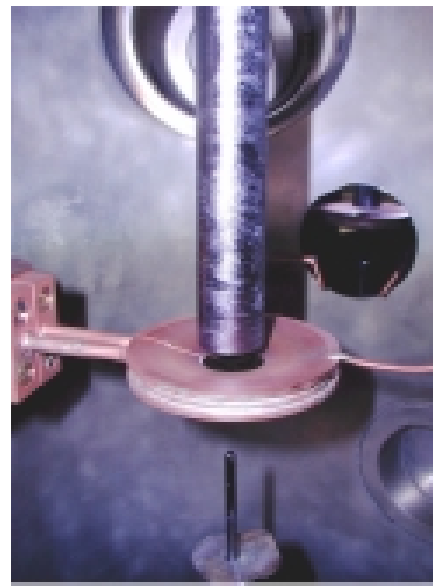

Fig. 1a. FZ set-up

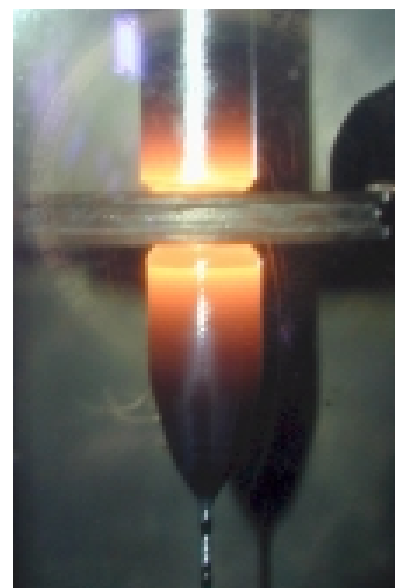

Fig. 1b. FZ growth stock occurred during the growth process. DF growth was maintained for about half the ingot length, then twins and later, grain boundaries formed. Figure 1 illustrates the set-up, growth, and finished ingot. Late in the growth process, floating clumps of particulates could be observed on the melt, and these grew in size and froze onto the ingot surface during the crystal termination (Fig. 1d). A similar particulate formation situation was seen using treated MG-Si feedstock, but was generally more severe, with DF growth terminating earlier and more massive particle clumps on the melt and freeze-out.

\section{Czochralski growth}

As for FZ growth, CZ growth from treated, high Bcontent, reject EG-Si material was characterized by a clean initial melt that allowed seeding and necking to initiate DF growth. The ambient was argon at 0.1 bar above atmospheric pressure. Induction heating at $0.4 \mathrm{MHz}$ melted the Si held in a stationary clear fused quartz crucible nested in a graphite susceptor. The growth rate was $1.5 \mathrm{~mm} / \mathrm{min}$ with a crystal rotation rate of $14 \mathrm{rpm}$. One small CZ crystal grown from the treated high-B EG-Si feedstock remained DF throughout its length. Two others initiated twins and later grain boundaries after roughly half of the melt was solidified. Clumps of particles could be seen on the frozen melt residue from these runs, similar

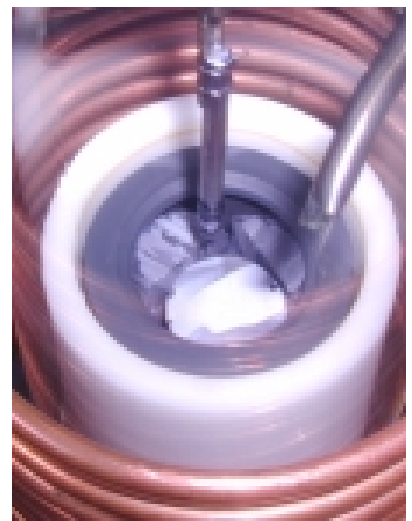

Fig. 2a. CZ set-up

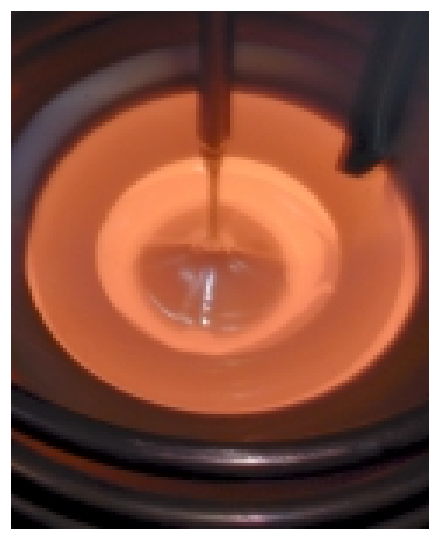

Fig. 2b. $<100>$ DF CZ growth

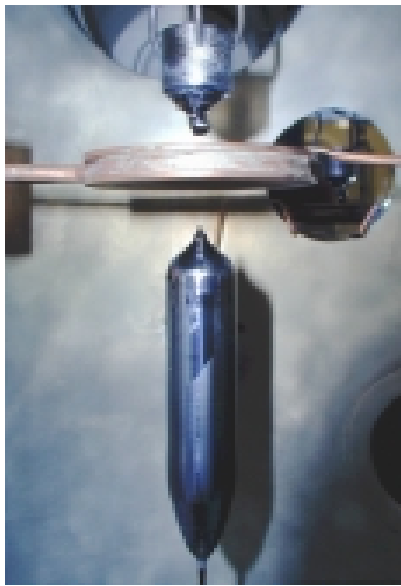

Fig. 1c. Finished FZ ingot

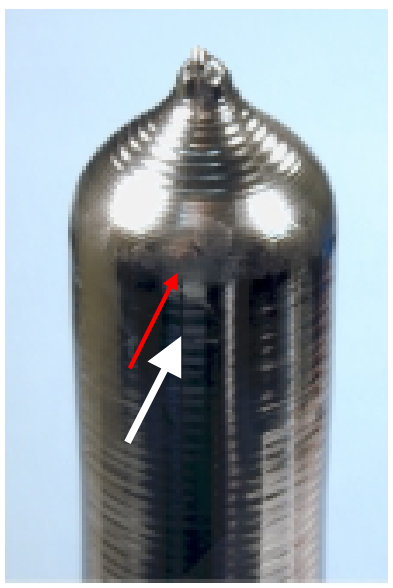

Fig. 1d. Frozen particulates to those observed in FZ growth. Figure 2 shows the setup, CZ growth, a finished CZ ingot, and an example of the particle clumps on a frozen melt residue surface. No CZ growth was attempted using treated MG-Si feedstock.

\section{FZ AND CZ CRYSTAL CHARACTERIZATION AND DIAGNOSTIC PV DEVICE RESULTS}

A Nomarski photomicrograph of a frozen particle clump that formed on the surface of a FZ crystal grown from treated MG-Si is shown in Fig. 3. The hexagonal morphology of the particles, coupled with electron probe micrograph analysis (EPMA) detection of high levels of $C$, provides at least circumstantial evidence for $\mathrm{SiC}$ particle composition-likely forming by precipitation from saturated carbon solubility levels in the melt.

Bulk determinations of $\mathrm{C}$ and $\mathrm{O}$ content in treated high-B EG-Si feedstock, CZ and FZ ingots grown from it, and a CZ ingot grown from EG-Si control feedstock (doped to $0.7 \Omega$-cm p-type) were made by Fourier transform infrared spectroscopy (FTIR). In Table I, higher levels of $C$ are seen in the treated EG-Si and the $C Z$ crystal grown from it than in the $\mathrm{CZ}$ crystal grown from high-purity EG-Si. O levels are comparable. Table 2 gives the measured impurity levels, by glow-discharge mass spectroscopy (GDMS), for the melt-treated high-B EG-Si feedstock, and for both CZ and FZ crystals grown

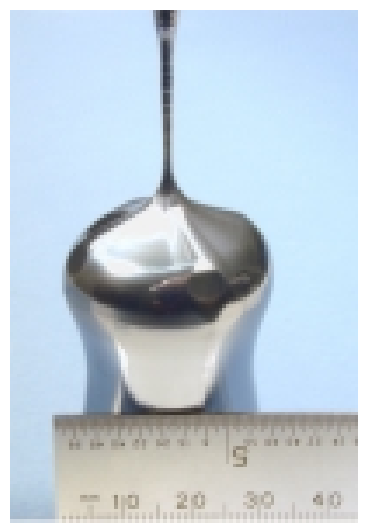

Fig. 2c. $<100>C Z$ ingot

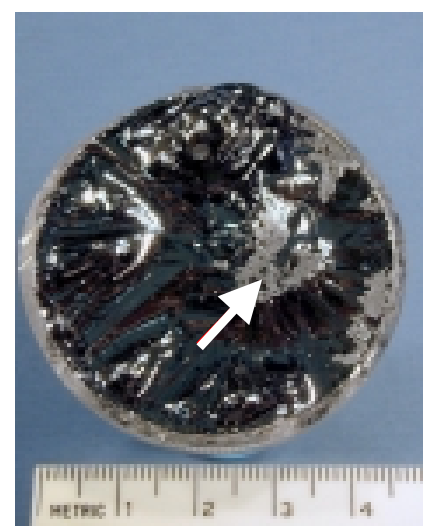

Fig. 2d. Particulate clumps 
Table I. Properties and Diagnostic Solar Cell Performance of Treated, High-B Reject EG-Si Feedstock, CZ and FZ Crystals Grown from It, and a CZ Control Crystal Grown from Doped EG-Si Feedstock.

\begin{tabular}{|l|l|c|c|c|c|c|}
\hline Sample & Source & $\begin{array}{c}\mathrm{C} \\
\left(\mathrm{cm}^{-3}\right)\end{array}$ & $\begin{array}{c}\mathrm{O} \\
\left(\mathrm{cm}^{-3}\right)\end{array}$ & $\begin{array}{c}\rho \\
(\Omega-\mathrm{cm})\end{array}$ & $\begin{array}{c}\text { Lifetime } \\
(\mu \mathrm{s})\end{array}$ & $\begin{array}{c}\text { Cell Efficiency } \\
\text { with ARC }\end{array}$ \\
\hline 3-28M5D & Treated hi-B EG-Si feedstock & $4 \times 10^{17}$ & $6 \times 10^{17}$ & 0.4 & $0.3-0.9$ & 8.3 \\
\hline CZ-010309 & CZ from treated hi-B EG-Si feedstock & $1 \times 10^{17}$ & $1 \times 10^{18}$ & 0.4 & $7-10$ & 14.0 \\
\hline FZ-010222 & FZ from treated hi-B EG-Si feedstock & $4 \times 10^{17}$ & $<1 \times 10^{17}$ & 0.4 & 130 & 13.8 \\
\hline CZ-010302 & Control CZ from EG-Si feedstock & $5 \times 10^{16}$ & $1 \times 10^{18}$ & 0.7 & $15-22$ & 14.1 \\
\hline
\end{tabular}

${ }^{*} \mathrm{ARC}-$ Antireflection Coating

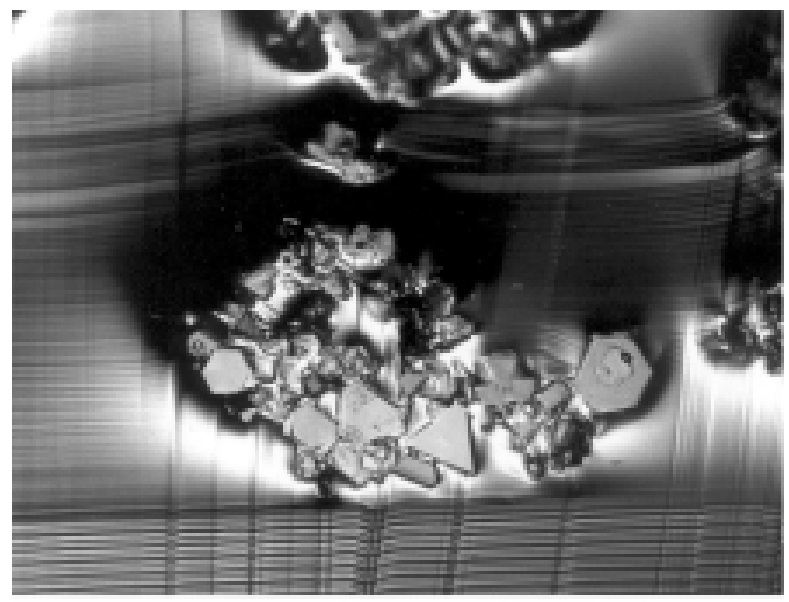

Fig. 3. Optical photomicrograph of a particle clump (the picture shows a 1-mm-wide region).

from the feedstock.

Table 2. Impurity Levels by GDMS

\begin{tabular}{|c|c|c|c|}
\hline Element & $\begin{array}{c}\text { Treated hi-B } \\
\text { EG-Si }\end{array}$ & $\begin{array}{c}\text { CZ from treated } \\
\text { hi-B EG-Si }\end{array}$ & $\begin{array}{c}\text { FZ from treated } \\
\text { hi-B EG-Si }\end{array}$ \\
\hline \hline $\mathrm{C}$ & 28.1 & 7.2 & 7.5 \\
\hline $\mathrm{O}$ & 21.1 & 15.1 & 7.5 \\
\hline $\mathrm{Al}$ & 0.24 & $<0.005$ & 0.042 \\
\hline $\mathrm{B}$ & 0.36 & 0.34 & 0.36 \\
\hline $\mathrm{P}$ & 0.10 & 0.054 & 0.073 \\
\hline $\mathrm{S}$ & $<0.04$ & $<0.04$ & $<0.04$ \\
\hline $\mathrm{Ca}$ & $<0.007$ & $<0.007$ & $<0.007$ \\
\hline $\mathrm{Fe}$ & $<0.005$ & $<0.005$ & $<0.005$ \\
\hline $\mathrm{Ge}$ & $<0.004$ & $<0.004$ & $<0.004$ \\
\hline $\mathrm{K}$ & $<0.007$ & $<0.007$ & $<0.007$ \\
\hline $\mathrm{As}$ & $<0.002$ & $<0.002$ & $<0.002$ \\
\hline $\mathrm{Co}$ & $<0.002$ & $<0.002$ & $<0.002$ \\
\hline $\mathrm{Cu}$ & $<0.002$ & $<0.002$ & $<0.002$ \\
\hline $\mathrm{Ni}$ & $<0.002$ & $<0.002$ & $<0.002$ \\
\hline $\mathrm{Zn}$ & $<0.002$ & $<0.002$ & $<0.002$ \\
\hline $\mathrm{Cr}$ & $<0.0005$ & $<0.0005$ & $<0.0005$ \\
\hline $\mathrm{Mg}$ & $<0.001$ & $<0.001$ & $<0.001$ \\
\hline $\mathrm{Mn}$ & $<0.0005$ & $<0.0005$ & $<0.0005$ \\
\hline $\mathrm{Na}$ & $<0.001$ & $<0.001$ & $<0.001$ \\
\hline $\mathrm{Sr}$ & $<0.0003$ & $<0.0003$ & $<0.0003$ \\
\hline $\mathrm{Ti}$ & $<0.0006$ & $<0.0006$ & $<0.0006$ \\
\hline $\mathrm{V}$ & $<0.0006$ & $<0.0006$ & $<0.0006$ \\
\hline $\mathrm{Zr}$ & $<0.0003$ & $<0.0003$ & $<0.0003$ \\
\hline & & & \\
\hline
\end{tabular}

The resistivity of a segment from treated high-B, EGSi feedstock was $0.4 \Omega-c m$, p-type; CZ and FZ crystals grown from other segments of treated high-B, EG-Si feedstock also had resistivities of $\sim 0.4 \Omega$-cm, p-type. Minority charge-carrier lifetime $\tau$ was measured by the photoconductive decay (PCD) method on the same segments and ingots using a 1064-nm light source. The treated feedstock had a lifetime of $0.3-0.9 \mu \mathrm{sec}$. The $C Z$ ingots had lifetimes of 7-10 $\mu \mathrm{sec}$ (treated reject high-B, EG-Si feedstock) and 15-22 $\mu \mathrm{sec}$ (high-purity EG-Si feedstock), respectively, and the FZ crystal lifetime was $130 \mu \mathrm{sec}$. Table I also shows the solar cell efficiencies obtained for 1$\mathrm{cm}^{2}$ diagnostic solar cell devices fabricated on wafers cut from these materials. Table 3 gives additional cell parameters (open circuit voltage $\mathrm{V}_{\text {oc }}$, shor-circuit current density $\mathrm{J}_{\mathrm{sc}}$, and fill factor FF) for these and for $\mathrm{FZ}$ and $\mathrm{CZ}$ commercial wafers that were similarly processed.

Table 3. Solar Cell Parameters

\begin{tabular}{|l|c|c|c|c|}
\hline \multicolumn{1}{|c|}{ Sample Description } & $\begin{array}{c}\mathrm{V}_{\mathrm{oc}} \\
(\mathrm{V})\end{array}$ & $\begin{array}{c}\mathrm{J}_{\mathrm{sc}} \\
\left(\mathrm{mA} / \mathrm{cm}^{2}\right)\end{array}$ & $\begin{array}{c}\mathrm{FF} \\
(\%)\end{array}$ & $\begin{array}{c}\text { Efficiency } \\
(\%)\end{array}$ \\
\hline \hline As-Treated hi-B EG-Si & 0.55 & 19.1 & 77.9 & 8.3 \\
\hline Baseline CZ From EG-Si & 0.60 & 30.9 & 76.7 & 14.1 \\
\hline CZ from treated hi-B EG-Si & 0.60 & 29.8 & 78.7 & 14.0 \\
\hline FZ from treated hi-B EG-Si & 0.59 & 30.1 & 77.7 & 13.8 \\
\hline Commercial FZ Wafer & 0.60 & 32.3 & 78.0 & 15.1 \\
\hline Commercial CZ Wafer & 0.60 & 29.9 & 80.1 & 14.3 \\
\hline
\end{tabular}

Diagnostic device I-V curves are shown in Fig. 4, and the corresponding internal quantum efficiencies, from which effective diffusion lengths were determined, are presented in Fig. 5. This small sampling of device performance indicates that devices made directly on gaseous melt-treated, reject, high-B, EG-Si feedstock have a little over half the efficiency of devices made from control $C Z$ samples. Their internal quantum efficiency falls off with increasing wavelength. However, devices on CZ and FZ crystals grown from the Crystal Systems-treated feedstock have comparable PV performance $(14.0 \%$ and $13.8 \%$ efficiency, respectively) to that of CZ control samples $(14.1 \%)$. 


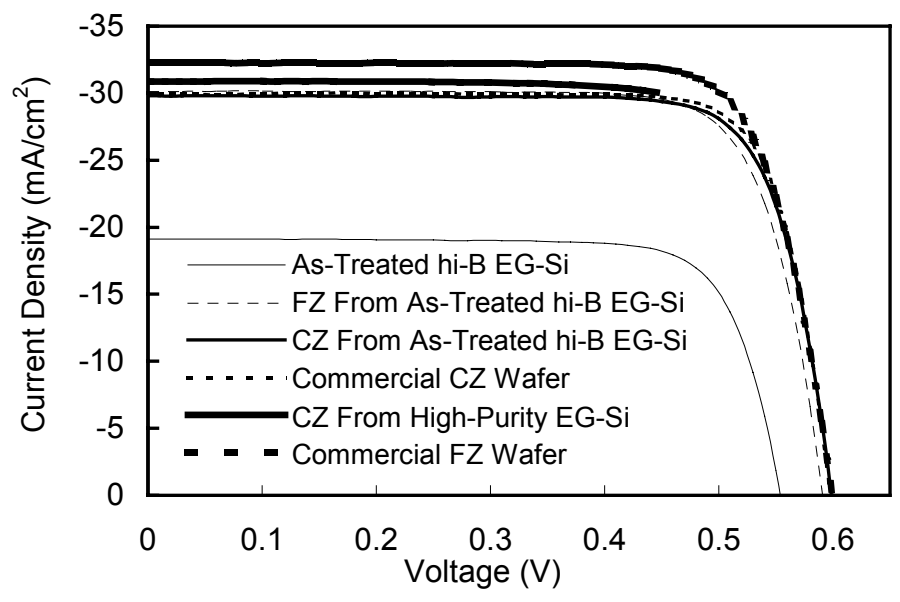

Fig. 4. Diagnostic solar cell I-V curves

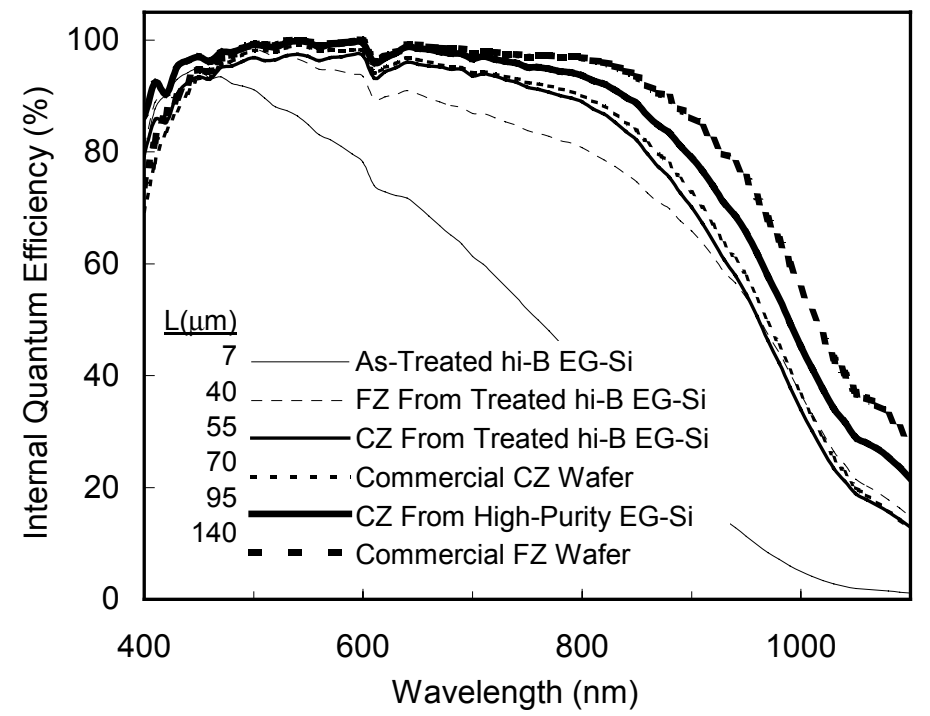

Fig. 5. Internal quantum efficiency and diffusion length for the cells of Fig. 4

\section{SUMMARY AND DISCUSSION}

FZ and CZ crystals were grown and characterized, and diagnostic solar cell devices were made, using a new type of SoG-Si feedstock developed by Crystal Systems-gaseous melt treated, high-B, EG-Si. Dislocationfree growth could be initiated by both methods. High feedstock carbon levels eventually supersaturated most of the melts and precipitated $\mathrm{SiC}$ particles. This is probably not a serious issue for multicrystalline growth methods, but it would be problematic for single-crystal growth. Additional efforts will be required to reduce the $\mathrm{C}$ content. The PV conversion efficiencies of $1-\mathrm{cm}^{2}$ devices made from $C Z$ crystals we grew using the new feedstock $(14 \%$, AR-coated) were similar to those from CZ crystals we grew using EG feedstock (14.1\%) and those we obtained using commercial <111> CZ wafers (14.3\%). Devices with an efficiency of $8.3 \%$ were also made directly on wafers cut from the treated high-B EG-Si feedstock. The wafers were also successfully used as substrates for epitaxial Si thin-layer growth.

\section{ACKNOWLEDGEMENTS}

The authors appreciate the assistance of C.P. Khattak and D.B. Joyce, who provided the core-drilled samples of experimental feedstock material, and NREL's Measurements and Characterization teams for assistance with PCD, FTIR, and EMPA analysis. This work was supported by DOE contract DE-AC36-99G010337.

\section{REFERENCES}

[1] Chandra P. Khattak, David B. Joyce, Frederick Schmid, Ted F. Ciszek, Matthew R. Page, and Martha I. Symko-Davies, "Solar Grade Silicon for Solar Cell Applications," to be published in proceedings of the $17^{\text {th }}$ European Photovoltaic Solar Energy Conference. 


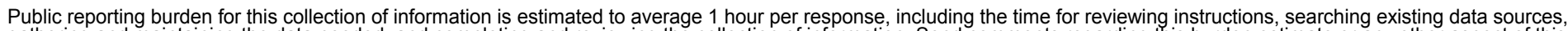

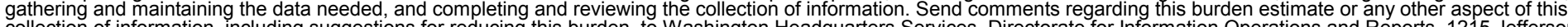
Davis Highway, Suite 1204, Arlington, VA 22202-4302, and to the Office of Management and Budget, Paperwork Reduction Project (0704-0188), Washington, DC 20503.
1. AGENCY USE ONLY (Leave blank)
2. REPORT DATE
May 2002
3. REPORT TYPE AND DATES COVERED
$29^{\text {th }}$ IEEE PVSC-Conference Paper
May 20-24 2002

4. TITLE AND SUBTITLE

Float-Zone and Czochralski Crystal Growth and Diagnostic Solar Cell Evaluation of a New Solar-Grade Feedstock Source: Preprint

6. $\operatorname{AUTHOR}(\mathrm{S})$

T.F. Ciszek, M.R. Page, T.H. Wang, and J.A. Casey

7. PERFORMING ORGANIZATION NAME(S) AND ADDRESS(ES) National Renewable Energy Laboratory 1617 Cole Blvd. Golden, CO 80401-3393

9. SPONSORING/MONITORING AGENCY NAME(S) AND ADDRESS(ES)

National Renewable Energy Laboratory

1617 Cole Blvd.

Golden, CO 80401-3393
5. FUNDING NUMBERS PVP24801

8. PERFORMING ORGANIZATION REPORT NUMBER

10. SPONSORING/MONITORING AGENCY REPORT NUMBER

NREL/CP-520-31442

11. SUPPLEMENTARY NOTES

12a. DISTRIBUTION/AVAILABILITY STATEMENT

National Technical Information Service

U.S. Department of Commerce

5285 Port Royal Road

Springfield, VA 22161

13. ABSTRACT (Maximum 200 words): This conference paper describes the Czochralski (CZ) and float-zone (FZ) crystals were grown from experimental solar-grade silicon (SOG-Si) feedstock materials developed by Crystal Systems. The materials were metallurgical-grade Si and highly boron-doped p-type electronic-grade Si (EG-Si) reject material, both of which were gaseous melt-treated to remove boron. Crystal growth observations, lifetime and impurity characterization of the grown crystals, and device performance of wafers from them are presented. Devices made directly on treated high-B EG-Si feedstock have a little over half the efficiency of devices made from control CZ samples. However, devices on CZ and FZ crystals grown from the treated high-B EG-Si feedstock have comparable PV performance $(14.0 \%$ and $13.8 \%$ efficiency, respectively) to that of CZ control samples (14.1\%).

14. SUBJECT TERMS: PV; Czochralski (CZ); float-zone (FZ) crystal; solar-grade silicon (SOG$\mathrm{Si})$; electronic grade Si (EG-Si); Normanski photomicrograph; Fourier transform infrared spectroscopy (FTIR); glow-discharge mass spectroscopy (GDMS); quantum efficiency; microcrystalline growth;

12b. DISTRIBUTION CODE

17. SECURITY CLASSIFICATION OF REPORT Unclassified
18. SECURITY CLASSIFICATION OF THIS PAGE Unclassified
19. SECURITY CLASSIFICATION OF ABSTRACT Unclassified
15. NUMBER OF PAGES

16. PRICE CODE UL 